\title{
Regression Analysis by Taguchi Method on Strength of Weathered Crystalline Rock Sand Concrete
}

\author{
Shaji M Jamal, T.R Neelakantan, Ramesh Babu Chokkalingam
}

\begin{abstract}
Due to industrialisation, large constructions are going on all over the world which in turn requires huge quantity of cement and sand. Cement manufacture is a main source of carbon-di-oxide emission to the atmosphere and quarrying of river sand produces scarcity as well as environmental problems. There are various waste products obtained from manufacture of other materials as well as from quarries, the handling of which is difficult and creates environmental issues. These waste materials can be used as a replacement for cement and sand. In this study weathered crystalline rock sand which is obtained from the soft outer portion of rock in quarries is used as replacement for river sand and Ground Granulated Blast-furnace Slag (GGBS) obtained from iron industry is used as replacement for cement to reduce the environmental impact as well as to help waste handling and reuse.
\end{abstract}

Keywords : weathered, crystalline, waste material-reuse, environmental hazards

\section{INTRODUCTION}

Concrete, a mixture of cement, fine aggregate, coarse aggregate, and water, is the most widely used man made material on earth. Fine aggregate (normally river sand) and cement are two of the major ingredients of concrete. Also fine aggregate is used as a main part in mortar for plastering and brick work. In early days river sand was abundantly available in our rivers and construction using this was not costly. But as the consumption of natural river sand has become excessive, the scarcity and in turn the cost of river sand has grown to such a level that, it has become impossible to use river sand for construction. Deeper river bottom, very low ground water level, etc are some of the impacts on environment due to the excessive river sand mining.

Besides issues related to sand, cement production also has some adverse effect on the atmosphere. Cement companies emit around 1.8GT/year carbon-di-oxide. This comes around $7 \%$ of the overall carbon-di-oxide emission. Second only to China, India produces cement about 135 MMT per annum; this is almost $6 \%$ of the global production. It makes use of

Revised Manuscript Received on December 5, 2019

* Correspondence Author

Shaji M Jamal*, Faculty, Ilahia College of Engg \& Tech, Muvattupuzha \& Research Scholar, KARE, Krishnankoil, India shaji@icet.ac.in

T.R Neelakantan, Dept of Civil Engineering, Kalasalingam Academy of Research and Education, Krishnankoil 626126, India. Email: neelakantan@klu.ac.in

Ramesh Babu Chokkalingam, , Dept of Civil Engineering, Kalasalingam Academy of Research and Education, Krishnankoil 626126, India. Email: c.rameshbabu@klu.ac.in large quantity of calcareous and aluminous raw materials. This results in scarcity of natural raw materials and environmental hazards. The main arguments against sand quarrying are with respect to protection of riverbeds from erosion and the relevance of natural sand as a ground water filter media.

The ever increasing demand for river sand and $\mathrm{CO}_{2}$ emission from cement industry has inspired engineers and scientist to search for new materials which can replace them.

Crushed aggregate, foundry sand, bottom ash, sheet Glass Powder [4] and many other by-products and waste materials can be replacement for natural sand. In tropical areas, a type of soft rock called "Weathered Crystalline Rock" is abundantly available as the top layer of the hard rock. This is to be removed and disposed off before quarrying the actual rock. This can be extracted from other places also. As this is a soft rock it is usually discarded and is a waste material and many times not utilized. In a preliminary study on strength of the sand produced from this rock, it is seen that this material can be used as a replacement for the sand.

In a similar way, GGBS, fly ash, silica fume, etc, are waste by-products obtained during manufacturing of other materials, which can be considered as partial or sometimes complete replacement for cement. In this study an attempt is made to try weathered crystalline rock as fine aggregate and GGBS as partial replacement for cement in high strength concrete [3] by investigating the strength of high grades of concrete. The experimental data is submitted to make a probabilistic model [13] of regression analysis based on Taguchi's Method using Minitab software. The obtained regression equation can be used to predict the strength of any concrete by inputting the other values viz., percentage replacement of cement by GGBS, percentage replacement of sand by WCRS and the curing age of concrete.

\section{EXISTING WORKS}

Studies related to replacement of sand with other waste materials tried to use manufactured fine aggregate from different sources. First of them was to use crushed rubble as fine aggregate and this has also similar problems of sand mining; it affects the environment. Another study was to try the fine dust, which is a waste product of fine and coarse aggregate production by crushing large rubble pieces. Other studies tested the use of marble chips which is a waste product of marble industry [12], by using crushed spent fire bricks [5], by using demolished waste concrete, etc. 
Studies have been undertaken to find the properties of fine aggregate produced from 'Weathered Crystalline Rock (WCR)' which is found in abundance in tropical areas. This rock is the outer layer of earth's crust and also it is soft in nature. These characteristics make it easy to quarry and to produce fine aggregate in a cost effective manner [2]. Even now people are using this by adding it to river sand but as there is not many studies have been carried out on the properties of this material, engineers don't recommend it and hence adding it to river sand is considered as adulteration [2]. In fact in many areas before quarrying rubble, this soft outer layer of rock has to be removed and if this can be used as a substitute for the fine aggregate, it will be a solution for the disposal of a waste material. The properties of fine aggregate produced from weathered crystalline rock like strength, specific gravity, etc are comparable with that of the manufactured fine aggregate and to some extent, that of river sand.

As in the case of sand, studies to replace cement partially or completely are also have been carried out using various waste and byproducts like ceramic powder and silica fume [18], metakaolin [19], palm oil fuel ash [20], GGBS, pulverized fuel ash, etc.

\section{OBJECTIVES}

Objectives of the study are the following:

- Study the compressive strength properties of M60 mix with partial and full replacement of fine aggregate with WCR sand

- Partial replacement of cement with GGBS and finding out the optimum percentage of GGBS.

- Develop a probabilistic model of the above M60 concrete using a regression analysis by means of Taguchi's method.

- Validation of the probabilistic model properties with regards to compressive strength of concrete through experimental study.

\section{TAGUCHI'S METHOD}

Genichi Taguchi developed a technique for the process of optimisation. In many of the experimental methods, which incorporates Taguchi's method of analysis reduces the number of experiments and this will obviously cut down the cost of optimisation. If in $m$ levels, we consider $n$ parameters, a total of $\mathrm{m} 3 \mathrm{n}$ experiments are needed for an optimal mix. For designing optimal levels of components, Taguchi method [15], [16] makes use of orthogonal array at the experimental study. This way, we can reduce the number of experiments. Analysis of results using standard orthogonal array, the Taguchi method utilizes a statistical performance measure, named Signal-to-Noise ratio (S-N ratio).

\section{METHODOLOGY}

\section{A. Material Selection}

Cement used in this study is Ordinary Portland Cement Grade 53. For normal mix, M-sand with size not more than $4.75 \mathrm{~mm}$ is used. For WCRS concrete, weathered crystalline rock with same specification as above is used. For all the mixes rubble is used as coarse aggregate [11]. GGBS supplied by JSW cements and modified polycarbxoylic ether based super plasticiser - 'Master Glenium SKY 8233' are used for the study. 'Alccofine 1203 ' is used as the mineral additive.

\section{B. Properties of selected materials}

Chemical properties of cement [21], GGBS [21] and weathered crystalline rock sand [2] from XRF analysis are given in Table 1. Physical properties of the ingredients are listed in Table 2.

TABLE I.

ChEMical Composition of MATERIALS USED IN THE STUDY

\begin{tabular}{|c|c|c|c|}
\hline \multirow{2}{*}{ Oxide (\%) } & \multicolumn{3}{|c|}{ Material Used } \\
\hline & GGBFS & OPC & WCRS \\
\hline $\mathrm{CaO}$ & 65.1 & 42.506 & 2.13 \\
\hline $\mathrm{SiO}_{2}$ & 24.78 & 41.06 & 67.62 \\
\hline $\mathrm{Al}_{2} \mathrm{O}_{3}$ & 1.71 & 5.105 & 16.1 \\
\hline $\mathrm{Fe}_{2} \mathrm{O}_{3}$ & 1.62 & -- & 3.84 \\
\hline MgO & 1.32 & 4.248 & 0.74 \\
\hline $\mathrm{Na}_{2} \mathrm{O}$ & 1.33 & 3.093 & 2.7 \\
\hline $\mathbf{K}_{2} \mathbf{O}$ & 0.81 & 0.685 & 5.7 \\
\hline $\mathrm{TiO}_{2}$ & 0.34 & 0.976 & 0.7 \\
\hline MnO & 0.039 & 0.655 & 0.07 \\
\hline $\mathbf{P}_{2} \mathbf{O}_{5}$ & 0.24 & 0.27 & 0.4 \\
\hline $\mathrm{SO}_{3}$ & 2.54 & 1.272 & -- \\
\hline SrO & 0.117 & 0.086 & -- \\
\hline $\mathrm{CuO}$ & 0.014 & -- & -- \\
\hline $\mathrm{Cl}^{-}$ & 0.04 & 0.044 & -- \\
\hline
\end{tabular}

TABLE II.

Physical Properties of Materials USed in the STUDY

\begin{tabular}{|c|c|c|c|c|}
\hline \multirow[b]{2}{*}{ Property } & \multicolumn{4}{|c|}{ Material } \\
\hline & Cement & $\begin{array}{l}\text { GGB } \\
\text { S }\end{array}$ & WCRS & M-Sand \\
\hline Specific Gravity & 3.15 & 2.96 & 2.73 & 2.74 \\
\hline Fineness modulus & -- & -- & 2.75 & 3.94 \\
\hline Fineness & 5 & 389 & -- & -- \\
\hline $\begin{array}{l}\text { Water Absorption } \\
(\%)\end{array}$ & -- & -- & 1.8 & 1.5 \\
\hline $\begin{array}{l}\text { Particle size } \\
\text { (microns) }\end{array}$ & -- & 97.1 & -- & -- \\
\hline $\begin{array}{l}\text { Standard } \\
\text { Consistency }(\%)\end{array}$ & 35 & -- & -- & -- \\
\hline $\begin{array}{l}\text { Initial setting time } \\
\text { (min) }\end{array}$ & 40 & -- & -- & -- \\
\hline
\end{tabular}

\section{Concrete mix design}

M60 mix was selected in this study of high strength concrete. 27 samples were tested for compressive strength, at different ages viz, 3 days, 7 days and 28 days. Although IS code says that characteristic compressive strength is to be tested at 28 days of curing, to get an idea of the attainment of strength in the early ages also, the former two age of concrete are also considered. 
As specific mix design for M60 mix is not available in codes, trial and error method of mix selection is done with the help of expertise from a Ready-mix Concrete Company.

Other relevant specifications of IS 456:2000 [7], guidelines from NMRCA and IS 10262:2009, IS 383:1970 [6], etc were also used in this study. Table 1 shows the quantities of constituent materials used in the trials. A final mix was selected for the experiment in which, 5\% of mineral admixture and $0.5 \%$ of super plasticizer are added and with a slump of $110 \mathrm{~mm}$. The proportion of the constituents in concrete are: Cement $-450 \mathrm{~kg}$, Coarse Aggregate $-1132 \mathrm{~kg}$, Fine Aggregate - 786.4, Water - $165 \mathrm{~kg}$, Mineral Admixture $-5 \%$, Super Plasticiser $-0.5 \%$ and slump value -110 .

\section{TEST FOR COMPRESSIVE STRENGTH}

Compressive strength tests were carried out using cubical specimen of size $150 \mathrm{~mm}$ x $150 \mathrm{~mm}$ x $150 \mathrm{~mm}$. Specimens were made as per IS 516: 1959 [8] using metal moulds. The concrete was filled into the mould in layers approximately $5 \mathrm{~cm}$ deep. Hand compaction was employed by subjecting concrete to not less than 35 strokes per layer using tamping rods of $16 \mathrm{~mm}$ diameter and $0.6 \mathrm{~m}$ long. Specimens were cured in the curing tank for specified period. Tests were done on the compression testing machine and ultimate loads in $\mathrm{N}$ were found out. Specimens were tested for 3, 7 and 28 days. 3 specimens were tested at each age. Compressive strength of the specimen in $\mathrm{N} / \mathrm{mm}^{2}$ is calculated as follows:

\section{Compressive strength $=$ Ultimate load $/$ Contact area}

The compressive strength of the 27 specimens tested is tabulated in table 3 . The table shows percentage replacement of WCRS (percentage by volume), GGBS and curing age of the specimens and the unconfined compressive strength of the samples.

Unconfined compressive strength with various specifications for different curing ages

TABLE III.

UNCONFINED COMPRESSIVE STRENGTH WITH VARIOUS SPECIFICATIONS For DifFERENT CURING AGES

\begin{tabular}{|c|c|c|c|c|}
\hline $\begin{array}{l}\text { Sp. } \\
\text { No }\end{array}$ & $\begin{array}{l}\text { WCRS } \\
(\%)\end{array}$ & $\begin{array}{l}\text { GGBS } \\
(\%)\end{array}$ & $\begin{array}{l}\text { Curing Age } \\
\text { (Days) }\end{array}$ & $\mathrm{UCS}\left(\mathrm{N} / \mathrm{mm}^{2}\right)$ \\
\hline 1 & 0 & 30 & 3 & 22.86 \\
\hline 2 & 0 & 30 & 7 & 47.53 \\
\hline 3 & 0 & 30 & 28 & 70.34 \\
\hline 4 & 50 & 30 & 3 & 20.91 \\
\hline 5 & 50 & 30 & 7 & 41.84 \\
\hline 6 & 50 & 30 & 28 & 66.65 \\
\hline 7 & 100 & 30 & 3 & 18.96 \\
\hline 8 & 100 & 30 & 7 & 36.14 \\
\hline 9 & 100 & 30 & 28 & 62.96 \\
\hline 10 & 0 & 40 & 3 & 25.86 \\
\hline 11 & 0 & 40 & 7 & 51.83 \\
\hline 12 & 0 & 40 & 28 & 73.16 \\
\hline 13 & 50 & 40 & 3 & 23.465 \\
\hline 14 & 50 & 40 & 7 & 4275 \\
\hline 15 & 50 & 40 & 28 & 71.09 \\
\hline 16 & 100 & 40 & 3 & 21.07 \\
\hline 17 & 100 & 40 & 7 & 39.85 \\
\hline 18 & 100 & 40 & 28 & 69.03 \\
\hline 19 & 0 & 50 & 3 & 25.86 \\
\hline 20 & 0 & 50 & 7 & 51.83 \\
\hline 21 & 0 & 50 & 28 & 69.27 \\
\hline
\end{tabular}

\begin{tabular}{|l|l|l|l|l|}
22 & 50 & 50 & 3 & 20.57 \\
\hline 23 & 50 & 50 & 7 & 43.615 \\
\hline 24 & 50 & 50 & 28 & 65.745 \\
\hline 25 & 100 & 50 & 3 & 17.77 \\
\hline 26 & 100 & 50 & 7 & 35.4 \\
\hline 27 & 100 & 50 & 28 & 62.22 \\
\hline
\end{tabular}

\section{STATICSTICAL ANALYSIS OF UCS}

Taguchi's method was executed to develop a probabilistic model of the compressive strength of different modified mixes. The model defines the effect of control factors such as the GGBS content ( $\%$ by volume), WCRS content ( $\%$ by volume) and the Curing Age (in days) on the compressive strength of the mix. By using this model, the governing factors can be controlled by reducing the error variance. For the analysis, WRS content (A), GGBFS content (B) and the curing age $(\mathrm{C})$ are considered as the independent variables and Unconfined Compressive Strength (UCS) is the dependent variable. The response can be expressed as a function of the independent variables as below.

$$
U C S=f(A, B, C)
$$

For the three variables, three levels of variations are considered in the analysis. That is $3^{3}$ mixes ( 27 mixes). From the observations, it was found that the minimum numbers of steps in analysis are 9 (L9). The following table gives the input values for the independent variables.

TABLE IV.

UNCONFINED COMPRESSIVE STRENGTH WITH VARIOUS SPECIFICATIONS FOR DIFFERENT CURING AGES

\begin{tabular}{|l|l|l|l|}
\hline Variable & Level 1 & Level 2 & Level 3 \\
\hline WRS (A) & 0 & 50 & 100 \\
\hline GGBFS (B) & 30 & 40 & 50 \\
\hline Curing Age (C) & 3 & 7 & 28 \\
\hline
\end{tabular}

The model regression equation will be of the following form:

$$
U C S=k_{1}+\left(k_{2} \times A\right)+\left(k_{3} \times B\right)+\left(k_{4} \times C\right)
$$

\section{Main Effect}

Main effect plot for means was obtained from analysis of the model. The following figure gives the main effect of the variables $\mathrm{A}, \mathrm{B}$ and $\mathrm{C}$ on $\mathrm{UCS}$.

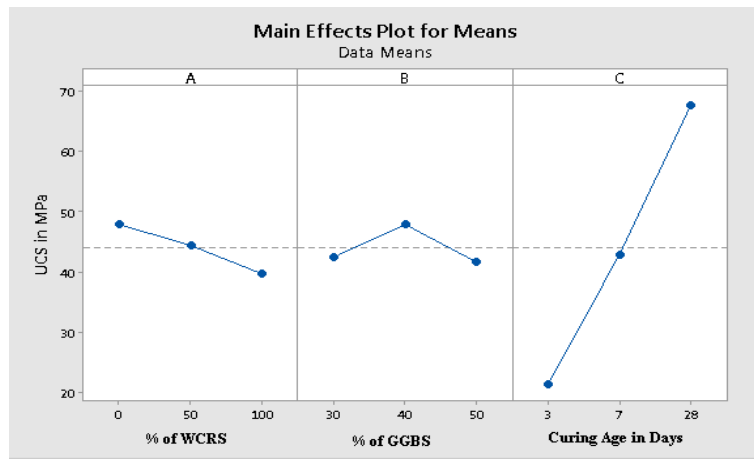

Fig. 1. Main effects plot for means 


\section{Regression Analysis by Taguchi Method on Strength of Weathered Crystalline Rock Sand Concrete}

From the main effect plot, it is obvious that the optimum strength was obtained when $0 \%$ WRS was used. Also the optimum results were observed for $40 \%$ of replacement of cement with GGBS. Obviously, 28 day strength was more than all the other curing ages.

\section{Signal to Noise Ratio ( $S-N$ Ratio)}

Main effect plot for S-N Ratio was plotted. Larger ratio is considered as better as aim is to optimize (Maximization problem) the compressive strength of the resulting concrete.

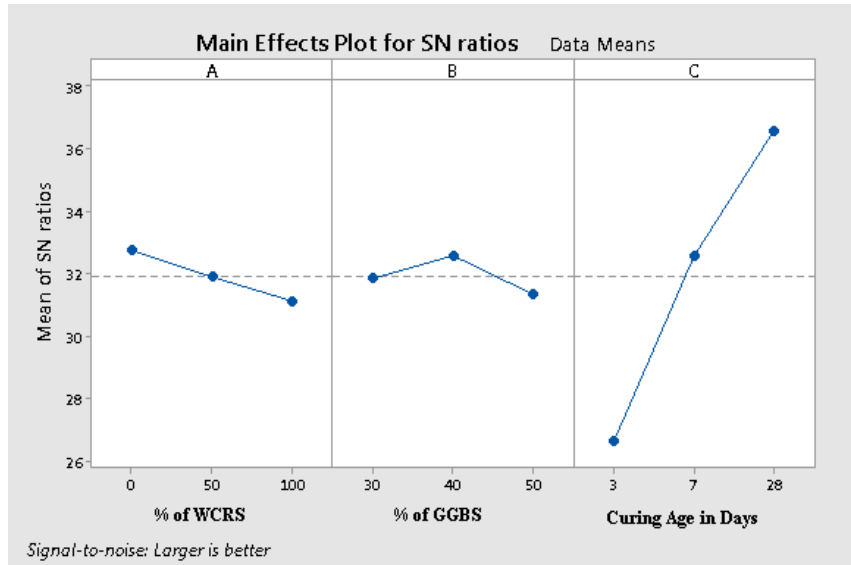

Fig. 2.Main effects plot for $\mathrm{S}-\mathrm{N}$ ratios

\section{Contour Plots}

Contours were plotted which can help in the interpolation of the responses. Three plots were made as UCS vs $(\mathrm{A}, \mathrm{B})$, UCS vs $(\mathrm{B}, \mathrm{C})$ and UCS vs $(\mathrm{A}, \mathrm{C})$. The following are the plots.

Contour plot of UCS vs percentage of WCRS and GGBS : For the plot UCS vs $(A, B)$, hold value for $C$ was 12.67.

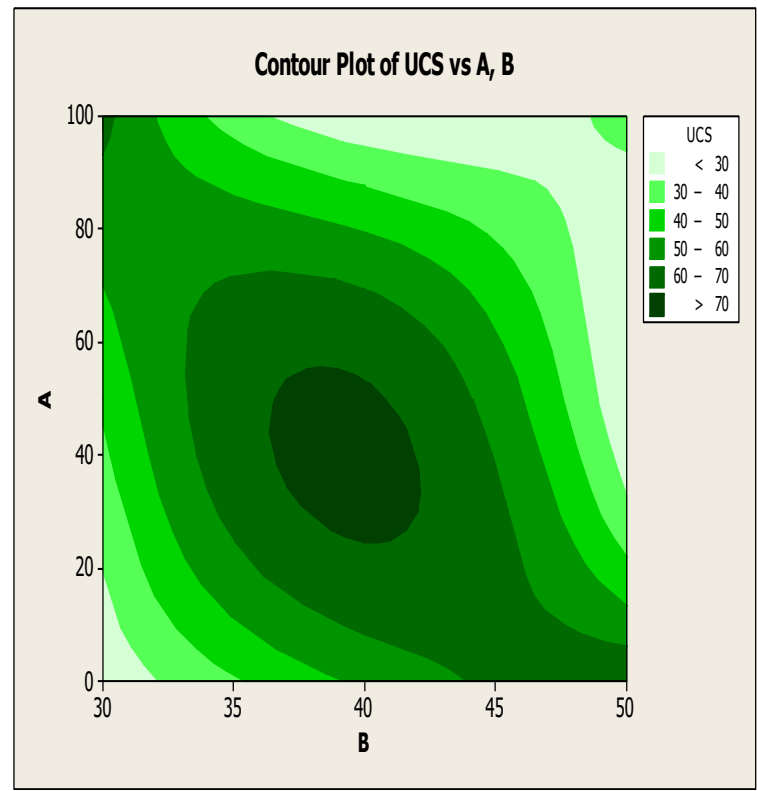

Fig. 3. Contour plot of UCS vs percentage of WCRS and GGBS

Contour plot of UCS vs percentage of GGBS and Curing Age: For the plot UCS vs $(B, C)$, hold value for A was 50.

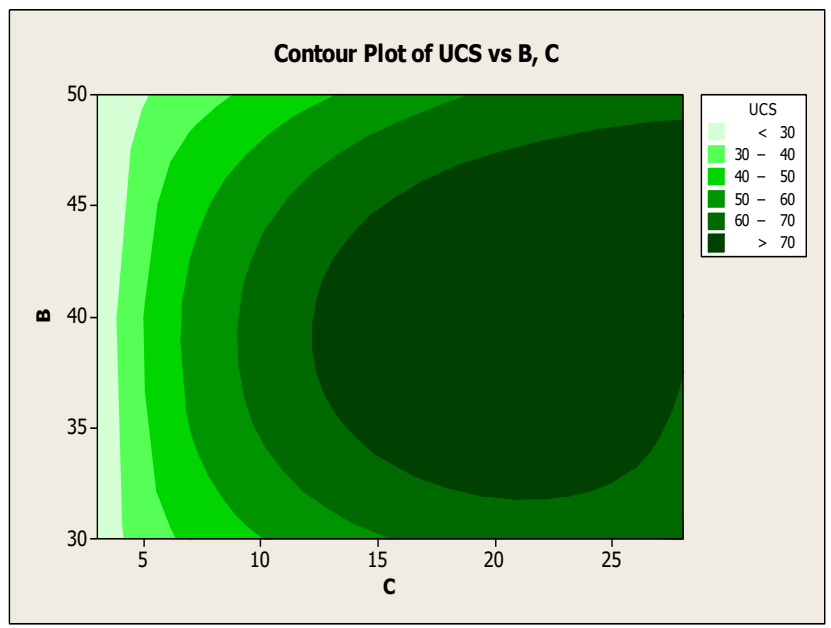

Fig. 4. Contour plot of UCS vs percentage of GGBS and Curing Age in days

Contour plot of UCS vs percentage of WCRS and Curing Age :For the plot UCS vs $(A, C)$, hold value for B was 40.

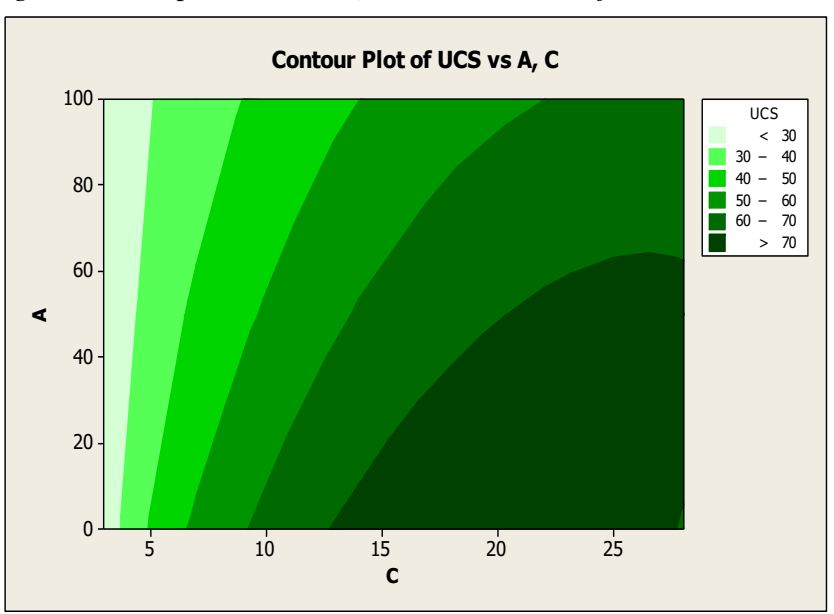

Fig. 5. Contour plot of UCS vs percentage of WCRS and Curing Age in days

\section{Regression Equation}

The regression equation of the analysis is as follows and the coefficients are given in the table.

$$
U C S=29.2-0.0819 A-0.040 B+1.63 C
$$

TABLE V.

COEEFICIENTS IN REGRESSION EQUATION

\begin{tabular}{|l|l|l|l|l|}
\hline Predictor & $\begin{array}{l}\text { Regrn. } \\
\text { Coeff }\end{array}$ & $\begin{array}{l}\text { Std. Error } \\
\text { in Coefft }\end{array}$ & T-Value & P-Value \\
\hline Constant & 29.16 & 16.13 & 1.81 & 0.130 \\
\hline A & -0.08190 & 0.07491 & -1.09 & 0.324 \\
\hline B & -0.0403 & 0.3745 & -0.11 & 0.918 \\
\hline C & 1.6294 & 0.2789 & 5.84 & 0.002 \\
\hline
\end{tabular}

$\mathrm{T}$-value measures the ratio between the coefficient and its standard error.

$\mathrm{P}$-value is a probability that measures the evidence against null hypothesis.

Figure 6 shown below is the comparison between experimental and predicted values in the study.

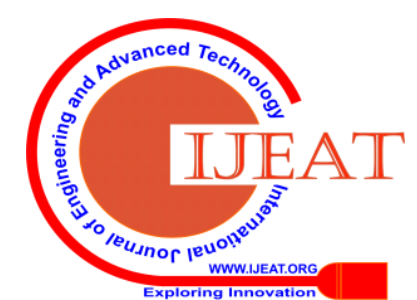




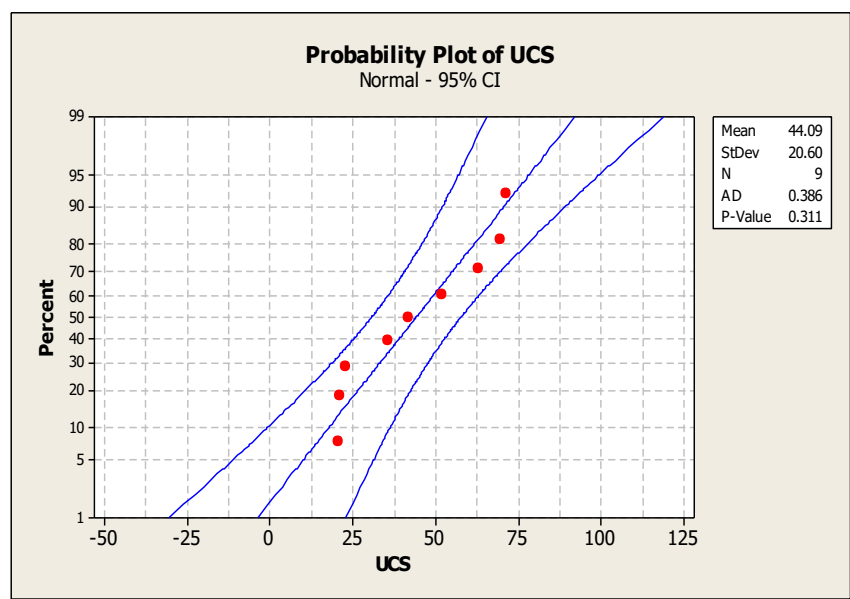

Fig. 6.Comparison between Experimental and Predicted Values

TABLE VI.

28 DAY COMPRESSIVE STRENGTH FROM BOTH EXPERIMENTAL AND ANALYTICAL METHODS - A COMPARISON FOR VARIOUS COMBINATIONS OF WCRS, GGBS AND CURING AGE

\begin{tabular}{|l|l|l|l|l|l|}
\hline $\begin{array}{l}\text { WRS } \\
(\%)\end{array}$ & $\begin{array}{l}\text { GGBS } \\
(\%)\end{array}$ & $\begin{array}{l}\text { UCS from } \\
\text { Experiment }\end{array}$ & $\begin{array}{l}\text { Predict } \\
\text { ed UCS }\end{array}$ & Difference & $\begin{array}{l}\% \\
\text { Variation }\end{array}$ \\
\hline 0 & 30 & 70.34 & 73.64 & 3.30 & 4.69 \\
\hline 50 & 30 & 66.65 & 69.55 & 2.90 & 4.34 \\
\hline 100 & 30 & 62.96 & 65.45 & 2.49 & 3.95 \\
\hline 0 & 40 & 73.16 & 73.24 & 0.08 & 0.11 \\
\hline 50 & 40 & 71.09 & 69.15 & -1.95 & -2.74 \\
\hline 100 & 40 & 69.03 & 65.05 & -3.98 & -5.77 \\
\hline 0 & 50 & 69.27 & 72.84 & 3.57 & 5.15 \\
\hline 50 & 50 & 65.745 & 68.75 & 3.00 & 4.56 \\
\hline 100 & 50 & 62.22 & 64.65 & 2.43 & 3.91 \\
\hline
\end{tabular}

\section{CONCLUSION}

The study aimed to analyse the Unconfined Compressive Strength of concrete made by partial replacement of cement with GGBS - a waste by-product - and partial and complete replacement of fine aggregate by Weathered Crystalline Rock Sand- a waste material from quarries - both by experimental results as well as analytical methods. In this study a probabilistic model of regression analysis using Taguchi's method is made and the regression equation is validated using the experimental data from 27 specimens, compared with predicted values. The following are the findings in the study:

- Taguchi's method of regression analysis is an approximate method but is simple and easy to implement.

- In this study, predicted values of early strength of concrete cubes viz., 3 day and 7 day strength show more difference from the experimental data. The accuracy of the Taguchi's method depends on the level selection for the experiment. The early strength attainment of concrete is a complicated process which depends upon a number of factors and variation of compressive strength of concrete is always non-linear during the early stages of curing while it is nearly linear when it approaches 28 days. So, it may require a higher order level selection than the selected $3^{\text {rd }}$ order level. This may be the reason for the large variation in predicted strength in early stages. Also, IS 456:2000 specifies that concrete's compressive strength is to be considered after 28 days of curing.

- It is seen that predicted 28 day compressive strength converges with the experimental data with a small difference of max $5 \%$.

- Hence the regression equation developed in this study can be used for the 28 day compressive strength prediction without much error.

\section{ACKNOWLEDGMENT}

The first author acknowledges the support rendered by Mr. Sreenath S, of Sastra University, Thanjaur, who helped a lot in learning Minitab software and its application, Mr. Basil Johny and Sreejith S from Ilahia College of Engg \& Tech, Muvattupuzha for their help in the experimental study.

\section{REFERENCES}

1. IS 10262: 2009, "Concrete Mix Proportioning - Guidelines (First Revision)”, Bureau of Indian Standards, New Delhi, July 2009.

2. Eldhose M Mathew, Shaji M Jamal, Ranjan Abraham, Weathered Crystalline Rock: Suitability as Fine Aggregate In Concrete - A Comparative Study, International Journal of Innovative Research in Science, Engineering and Technology, Vol. 2, Issue 4, April 2013

3. Michael A. Caldarone, High-Strength Concrete: A Practical Guide, USA, 2009

4. Mageswari M. and Vidivelli B, The use of Sheet Glass Powder (SHP) as Fine Aggregate Replacement (FAR) in concrete, Open Civil Engg. J., 4(1), 65-71, (2010).

5. Keerthinarayana, S, Srinivasan, R, Study On Strength And Durability Of Concrete By Partial Replacement Of Fine Aggregate Using Crushed Spent Fire Bricks, Bul. Inst. Polit. Iaşi, t. LVI (LX), f.2, 2010.

6. IS 383:1970, "Indian Standard specification for coarse and fine aggregates from natural sources for concrete”, Bureau of Indian Standards, New Delhi, April 1971

7. IS 456:2000, "Indian Standard code for Plain and reinforced concreteCode of practice”, Bureau of Indian Standards, New Delhi, July 2000.

8. IS 516:1959,"Indian Standard code for Methods of tests for strength of concrete”, Bureau of Indian Standards, New Delhi, Edition 1.2, 1991-07.

9. IS 1199:1959, "Indian Standard code for Methods of sampling and analysis of concrete", Bureau of Indian Standards, New Delhi, December 1959.

10. IS 2386:1963(Part I-VIII), "Indian Standard code Methods of test for aggregates for concrete”, Bureau of Indian Standards, New Delhi, 1963.

11. IS 2430:1969, "Indian Standard code for Methods for sampling of aggregates for concrete”, Bureau of Indian Standards, New Delhi, June 1987

12. Shah V., Bishnoi S. (2015) Use of Marble Dust as Clinker Replacement in Cements. In: Matsagar V. (eds) Advances in Structural Engineering. Springer, New Delhi.

13. Parthiban Kathirvel and Saravana Raja Mohan Kaliyaperumal, Probabilistic modeling of geopolymer concrete using response surface methodology, Computers and Concrete, Volume 19, Number 6, June 2017, pages 737-744

14. Wen-Ten Kuo, Her-Yung Wang, Chun-Ya Shu, Engineering properties of cement-less concrete produced from GGBFS and recycled desulfurization slag, Construction and_Building Materials Volume 63, 30 July 2014, Pages 189-196 
15. Mehmet Uzun1, Kemal Armagan, Optimization of Compressive Strength of Concrete Added Glass Powder Using Taguchi Methods, International Journal of Scientific Research Engineering \& Technology (IJSRET), ISSN 2278 - 0882 Volume 7, Issue 12, December 2018

16. Seyed Hamid Hashemi, Abed Soleymani, Optimization of HSC Compressive Strength by Taguchi Method, Applied Mechanics and Materials Vols. 253-255 (2013) pp 572-575 (C) (2013) Trans Tech Publications, Switzerland.

17. Hanifi Binici a, Orhan Aksogan b, Ismail H. Cagatay b, Mustafa Tokyay c, Engin Emsen, The effect of particle size distribution on the properties of blended cements incorporating GGBFS and natural pozzolan (NP), Powder Technology 177 (2007) 140-147.

18. Comparative study on strength properties of cement mortar by partial replacement of cement with ceramic powder and silica fume $\mathrm{Ch}$. Himabindu, Ch. Geethasri, and N. Hari.

19. Compressive strength of concrete by partial replacement of cement with metakaolin Y. S. V. Ganesh, P. Durgaiyya, Ch. Shivanarayana, and D. S. V. Prasad.

20. Properties of fresh and hardened sustainable concrete due to the use of palm oil fuel ash as cement replacement To cite this article: Hussein M Hamada et al 2018 IOP Conf. Ser.: Mater. Sci. Eng. 342012035.

21. Ali Shubbar, Hassnen Mosa Jafer, Anmar Dulaimi, Duaa AL-Faluji, The Development of a New Cementitious Material Produced from Cement and GGBS, Conference: The 3rd BUiD Doctoral Research Conference, At: The British University in Dubai, UAE, May 2017

\section{AUTHORS PROFILE}

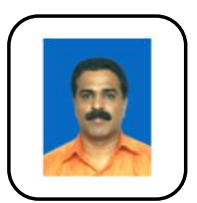

Shaji M Jamal, is a senior teacher in the department of Civil Engineering at Ilahia College of Engineering and Technology, Muvattupuzha, Kerala. He is pursuing Ph.D in Kalasalingam Academy of Research and Education, Krishnankoil, Tamilnadu.

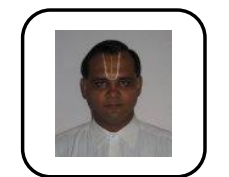

Dr. T.R. Neelakantan is a Senior Professor in Civil Engineering and Director - Accreditation and Ranking at Kalasalingam Academy of Research and Education, Tamilnadu. He obtained his Ph.D. degree in Civil Engineering from Anna University in the year 1998. His working experiences are from Anna University, IIT-Madras, SASTRA Deemed University and the University of Kentucky, Lexington, USA. He published more than 60 articles in reputed journals, and handled many government and private funded projects both in India and USA.

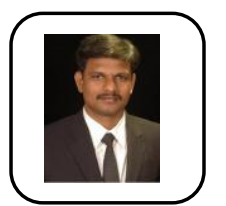

Dr. Ramesh Babu Chokkalingam completed his Ph.D. from IIT Chennai. He has more than ten years of experience in teaching and research. His areas of research includes pervious concrete, geopolymer concrete, and high volume flyash concrete. 